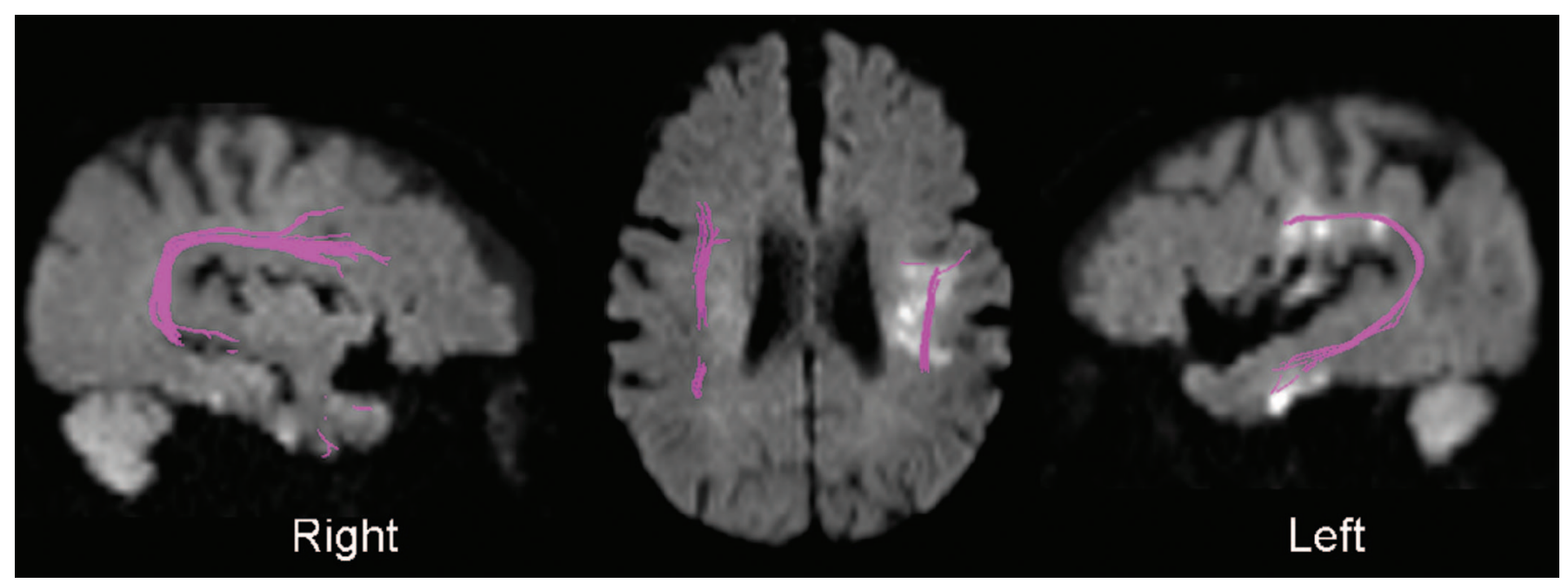

Figure. Tractography was done using DWI obtained in 4 minutes. The arcuate fasciculi (shown in purple) are seen superimposed on the DWI. Note that the arcuate fasciculus (AF) is smaller on the left side. Size laterality may exist in normal subjects, but usually the AF is smaller on the right side. ${ }^{2}$ The measured anisotropy index (fractional anisotropy) was 0.43 \pm 0.10 for the lesional fibers and $0.46 \pm 0.10$ for the contralesional fibers. Lower anisotropy for the lesional fibers may have indicated damage to the tract.

\section{VIDE0 MR tractography depicting damage to the arcuate fasciculus in a patient with conduction aphasia}

K. Yamada, MD, PhD; Y. Nagakane, MD; T. Mizuno, $M D, P h D$; A. Hosomi, $M D ;$ M. Nakagawa, $M D, P h D$; and T. Nishimura, MD, PhD, Kyoto, Japan

An 84-year-old right-handed man with a history of atrial fibrillation and a left parietal lobe infarct was admitted to the stroke unit due to a sudden decline in responsiveness. He was awake but

Additional material related to this article can be found on the Neurology Web site. Go to www.neurology.org and scroll down the Table of Contents for the March 6 issue to find the title link for this article. silent, though his comprehension was intact. Slight weakness was noted in his right upper and lower extremities. On the third day, the patient regained his voice, but his speech was impaired with paraphasic errors and naming difficulties. Repetition was markedly impaired. The clinical findings suggested motor/conduction aphasia. An MR examination showed a left middle cerebral artery infarction involving the parietal lobe. Since both the Broca and Wernicke areas were not directly involved on the diffusionweighted imaging (DWI) study, we did MR tractography on the assumption that the left arcuate fasciculus may be damaged. These images revealed a brain infarct completely engulfing the left arcuate fasciculus, supporting the diagnosis of conduction aphasia $^{1}$ (figure; see also the video at www.neurology.org).

1. Geschwind N. Disconnexion syndromes in animals and man. Brain 1965; 88:237-294.

2. Nucifora PG, Verma R, Melhem ER, Gur RE, Gur RC. Leftward asymmetry in relative fiber density of the arcuate fasciculus. Neuroreport 2005;16:791-794.

Disclosure: The authors report no conflicts of interest.

Address correspondence and reprint requests to Dr. Kei Yamada, Department of Radiology, Kyoto Prefectural University of Medicine, Kajii-cyo, Kawaramachi Hirokoji Agaru, Kamigyo-ku, Kyoto City, Kyoto 602-8566, Japan; e-mail: kyamada@koto.kpu-m.ac.jp 


\section{Neurology}

\section{MR tractography depicting damage to the arcuate fasciculus in a patient with conduction aphasia}

K. Yamada, Y. Nagakane, T. Mizuno, et al.

Neurology 2007;68;789

DOI 10.1212/01.wnl.0000256348.65744.b2

\section{This information is current as of March 5, 2007}

\section{Updated Information \&} Services

Supplementary Material

\section{References}

Citations

Permissions \& Licensing

Reprints including high resolution figures, can be found at: http://n.neurology.org/content/68/10/789.full

Supplementary material can be found at: http://n.neurology.org/content/suppl/2007/03/03/68.10.789.DC1

This article cites 2 articles, 0 of which you can access for free at: http://n.neurology.org/content/68/10/789.full\#ref-list-1

This article has been cited by 2 HighWire-hosted articles: http://n.neurology.org/content/68/10/789.full\#\#otherarticles

Information about reproducing this article in parts (figures,tables) or in its entirety can be found online at:

http://www.neurology.org/about/about_the_journal\#permissions

Information about ordering reprints can be found online:

http://n.neurology.org/subscribers/advertise

Neurology ${ }^{\circledR}$ is the official journal of the American Academy of Neurology. Published continuously since 1951, it is now a weekly with 48 issues per year. Copyright . All rights reserved. Print ISSN: 0028-3878. Online ISSN: 1526-632X.

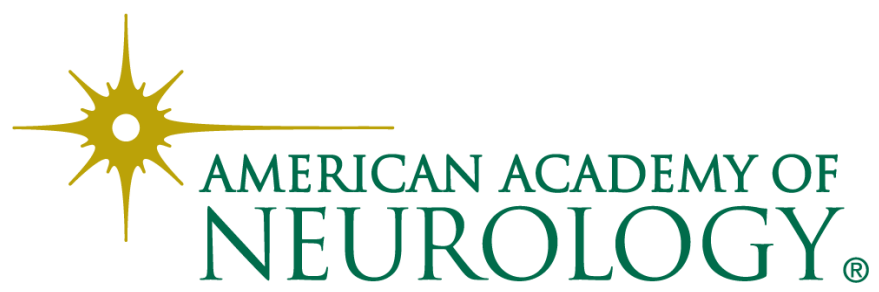

